\title{
Social and behavioral risk reduction strategies for tuberculosis prevention in Canadian Inuit communities: a cost- effectiveness analysis
}

Aashna Uppal 1,2,3,4, Olivia Oxlade ${ }^{2,3}$, Ntwali Placide Nsengiyumva ${ }^{2,3}$, Dieynaba S. N'Diaye ${ }^{1,2,3,4}$, Gonzalo G. Alvarez ${ }^{5}$ and Kevin Schwartzman ${ }^{1,2,3,4^{*}}$ (D)

\begin{abstract}
Background: Tuberculosis (TB) is an important public health problem in Inuit communities across Canada, with an annual incidence rate in 2017 that was nearly 300 times higher than in Canadian-born non-Indigenous individuals. Social and behavioral factors that are prevalent in the North, such as commercial tobacco use, excessive alcohol use, food insecurity and overcrowded housing put individuals at higher risk for TB morbidity and mortality. We examined the potential impact of mitigation strategies for these risk factors, in reducing TB burden in this setting.

Methods: We created a transmission model to simulate the epidemiology of TB in Nunavut, Canada. We then used a decision analysis model to assess the potential impact of several evidence-based strategies targeting tobacco use, excessive alcohol use, food insecurity and overcrowded housing. We predicted TB incidence, TB-related deaths, quality adjusted life years (QALYs), and associated costs and cost-effectiveness over 20 years. All costs were expressed in 2018 Canadian dollars.

Results: Compared to a status quo scenario with no new interventions for these risk factors, the reduction strategy for tobacco use was most effective and cost-effective, reducing TB incidence by 5.5\% (95\% uncertainty range: $2.7-$ $11 \%)$ over 20 years, with an estimated cost of $\$ 95,835$ per TB case prevented and $\$ 49,671$ per QALY gained. The addition of the food insecurity reduction strategy reduced incidence by a further $2 \%(0.5-3 \%)$ compared to the tobacco cessation strategy alone, but at significant cost.

(Continued on next page)
\end{abstract}

\footnotetext{
* Correspondence: kevin.schwartzman@mcgill.ca

${ }^{1}$ Montreal Chest Institute, Montreal, Quebec, Canada

${ }^{2}$ Respiratory Epidemiology and Clinical Research Unit, Centre for Outcomes

Research and Evaluation, Research Institute of McGill University Health

Centre, Montreal, Quebec, Canada

Full list of author information is available at the end of the article
}

C C The Author(s). 2021 Open Access This article is licensed under a Creative Commons Attribution 4.0 International License, which permits use, sharing, adaptation, distribution and reproduction in any medium or format, as long as you give appropriate credit to the original author(s) and the source, provide a link to the Creative Commons licence, and indicate if changes were made. The images or other third party material in this article are included in the article's Creative Commons licence, unless indicated otherwise in a credit line to the material. If material is not included in the article's Creative Commons licence and your intended use is not permitted by statutory regulation or exceeds the permitted use, you will need to obtain permission directly from the copyright holder. To view a copy of this licence, visit http://creativecommons.org/licenses/by/4.0/ The Creative Commons Public Domain Dedication waiver (http://creativecommons.org/publicdomain/zero/1.0/) applies to the data made available in this article, unless otherwise stated in a credit line to the data. 


\begin{abstract}
(Continued from previous page)
Conclusions: Strategies that aim to reduce commercial tobacco use and improve food security will likely lead to modest reductions in TB morbidity and mortality. Although important for the communities, strategies that address excess alcohol use and overcrowding will likely have a more limited impact on TB-related outcomes at current scale, and are associated with much higher cost. Their benefits will be more substantial with scale up, which will also likely have important downstream impacts such as improved mental health, educational attainment and food security.
\end{abstract}

Keywords: Cost-effectiveness, Decision analysis, Tuberculosis, Tobacco, Alcohol, Food insecurity, Overcrowding, Inuit, Nunavut

\section{Background}

Tuberculosis (TB) remains the deadliest infectious disease worldwide, with 1.4 million deaths in 2019 [1]. It is often the most vulnerable people who bear a disproportionate burden of TB morbidity and mortality; this is the case with Indigenous peoples [2]. This reflects colonization and disenfranchisement, as well as a high prevalence of risk factors for $\mathrm{TB}$ in many Indigenous communities, such as Aboriginal peoples and Torres Strait Islanders in Australia, Maori communities in New Zealand, and Inuit, First Nations and Métis communities in Canada. These risk factors include diabetes, alcohol and other substance use, cigarette smoking, food insecurity, and overcrowded housing [2].

Canada is among the countries with the lowest overall TB incidence. However, the disease is concentrated in Canadian Indigenous communities, particularly in the North [3]. TB was introduced to the Eastern Canadian Arctic in the 1800s following European settlement in the region [4]. After a steady decline over the latter half of the twentieth century, there has been a recent resurgence of TB in Inuit communities across Canada, with an annual incidence rate in 2017 that was 400 times higher than in Canadian-born non-Indigenous individuals (an incidence rate of 4.9 per 100,000 in Canada, 0.5 per 100,000 in Canadian-born non-Indigenous individuals, and 205.8 per 100,000 in Inuit communities) $[4,5]$. In this context, it is important to consider the role of social and behavioural factors, in addition to other biological or environmental factors, that put individuals at higher risk for TB morbidity and mortality.

Our study focuses on Nunavut, the largest region of the Inuit Nunangat (Inuit homeland). We consider four highly prevalent social and behavioral risk factors for TB: commercial tobacco use, heavy alcohol consumption (which we refer to as heavy drinking), food insecurity, and overcrowded housing, all of which are associated with increased risk of TB, and some with poorer outcomes. In 2014, Nunavut's population aged over 12 had the highest proportion of commercial tobacco smokers of all Canadian provinces and territories, with $62 \%$ estimated to be current smokers [6]. Although 14\% reported heavy drinking, similar to $16 \%$ in the rest of Canada, there is likely underreporting because of legal restrictions and contraband use [6, 7]. In 2012, 56\% of Nunavut households were food insecure, and in 2016, the same percentage of individuals lived in overcrowded dwellings (defined as more than one person per room) $[8,9]$ compared to $8 \%$ food insecure households and $2 \%$ in overcrowded dwellings, in the rest of Canada [9-11].

These risk factors affect TB pathogenesis in different ways. Smoking is associated with substantially increased risk of acquiring $\mathrm{TB}$ infection, progression to $\mathrm{TB}$ disease and TB-related death, possibly as the result of impaired immunity [11-13]. Excessive alcohol use is associated with increased susceptibility to TB infection and disease, and poorer treatment outcomes due to suboptimal adherence [14, 15]. Food insecurity increases the risk of TB infection and poor treatment outcomes such as treatment failure and death [16, 17]. Finally, crowded housing is associated with a higher contact rate between individuals, thereby increasing the likelihood of $M$. tuberculosis transmission [18-20]. There exist culturally appropriate programs to address these risk factors; for example, plain packaging was introduced for commercial tobacco products in Aboriginal communities in Australia [2]. Similarly, in several Nunavut communities, an inpatient program focused on clinical and cultural healing is designed to reduce heavy drinking [21].

Current approaches to TB prevention, detection and care in Nunavut include (but are not limited to) screening, contact investigation, active surveillance, molecular diagnostics such as the Xpert ${ }^{\circ}$ MTB/RIF test, and case management in accordance with the Canadian Tuberculosis Standards [22]. On the other hand, the current TB program does not specifically address social and behavioral risk factors for TB. Given their high prevalence in Nunavut and their association with TB morbidity and mortality, our objective is to assess the contribution of programs that reduce their prevalence. Specifically, we use simulation modeling to estimate the potential impact of several evidence-based strategies targeting four risk factors, considering TB-related health outcomes, associated costs and 
cost-effectiveness over 20 years from the government payer perspective.

\section{Methods}

We built two simulation models. The first, a dynamic transmission model, simulated the historic and recent TB epidemics in Nunavut, in order to estimate the distribution of TB-related health states in the general population in 2018 (e.g. the proportion of the population susceptible to $\mathrm{TB}$, the proportion latently infected, as these are not directly measured or known). The second was a decision analysis model, which involved using the 2018 population distribution (obtained from the dynamic model) to then evaluate the cost-effectiveness of various risk factor reduction strategies over the following 20 years. Each model is described in further detail below.

\section{Dynamic model}

A dynamic transmission model was first created and validated to simulate the TB epidemic in Nunavut from 1948 to 2018. This model's structure was adapted from a previously published model [23]. The previous model only considered smoking as a risk factor; we integrated three additional risk factors: excessive alchol use, food insecurity and overcrowded housing. This model captured the preantibiotic period, the shift in Inuit living conditions, the introduction of antibiotics, and recent prevention and care measures. Model parameters were based on published literature, whilst unknown parameters were based on observed data. By simulating the spread of TB in this region, we were able to estimate the distribution of the population with respect to the four risk factors as well TB-related health states in 2018, which included the proportion of the population uninfected by Mycobacterium tuberculosis, the proportion of the population with latent infection, and proportion of the population who had recovered from active disease. Pathogenetic parameters that were calibrated in the dynamic model were also applied to the decision analysis model (see Additional file 1, which also provides more details of the dynamic model).

\section{Decision analysis model}

Using TreeAge Pro software (TreeAge Software Inc., 2018, Williamstown, MA), we created a Markov decision analysis model which simulated a cohort of Canadian Inuit with median age 20 [24], starting in 2018 [25, 26]. As with the dynamic model, the model structure was modified from a previous version that considered only smoking as a risk factor [23]; a simplified schematic presentation of its structure is shown in Fig. 1. This model was used to predict TB-related health outcomes and TB-related health system costs over a 20 -year period after the implementation of the risk factor reduction strategies, compared with a status quo scenario without the implementation of these specific risk factor reduction strategies. The status quo scenario incorporated the current standard of $\mathrm{TB}$ care in the region. The health outcomes considered were TB incidence, TB-related deaths and TB-related quality adjusted life-years (QALYs). A discount rate of 3\% was applied to all future outcomes and costs [27].

\section{Data used in the decision analysis model}

Parameters used in the decision analysis model fell into four main categories: (1) TB pathogenetic and epidemiologic parameters, (2) TB-related health utilities, (3) TB risk factor reduction strategies' costs and effects, and (4) TB-related health system costs.

TB pathogenetic and epidemiologic parameters were informed by published data, or where necessary were calibrated using our dynamic model. Systematic reviews and meta-analyses were used to inform epidemiologic parameters describing the effect of each social and behavioural risk factor on TB pathogenesis. TB-related health utilities generally also came from published literature. On the other hand, data related to the costs and effects of TB risk factor reduction strategies came from actual program data, where possible, as described below. Finally, TB-related health system costs reflected publications from Nunavut, or other comparable settings. We distinguish two types of costs used in the model: those related to risk factor reduction strategies and those related to TB care (which we refer to as TB-related health system costs). [A full list of model parameters along with specific data sources is provided in Additional file 1 Supplemental Table 5.]

\section{TB pathogenetic and epidemiologic parameters}

Table 1 shows the key decision analysis model parameters related to TB pathogenesis, epidemiology and treatment. These parameters were used to define the probability of events occurring in the model (as onetime percentages, unless otherwise stated). For the population exposed to a combination of risk factors, the values for the relevant parameters were multiplied by the corresponding estimates of effect for the risk factors (Table 2).

\section{TB-related health utilities}

In order to estimate QALYs associated with TB, we used TB-related health utility weights from 0 to 1 (where 0 is death and 1 is perfect health) [42]. Scores were calculated based on the length of time spent with or without active TB or LTBI treatment. As latent TB is asymptomatic by definition, we considered that persons with LTBI who are untreated have the same health utility value as persons in perfect health, i.e. a value of 1 . We did not consider utility weights associated with TB risk factors 


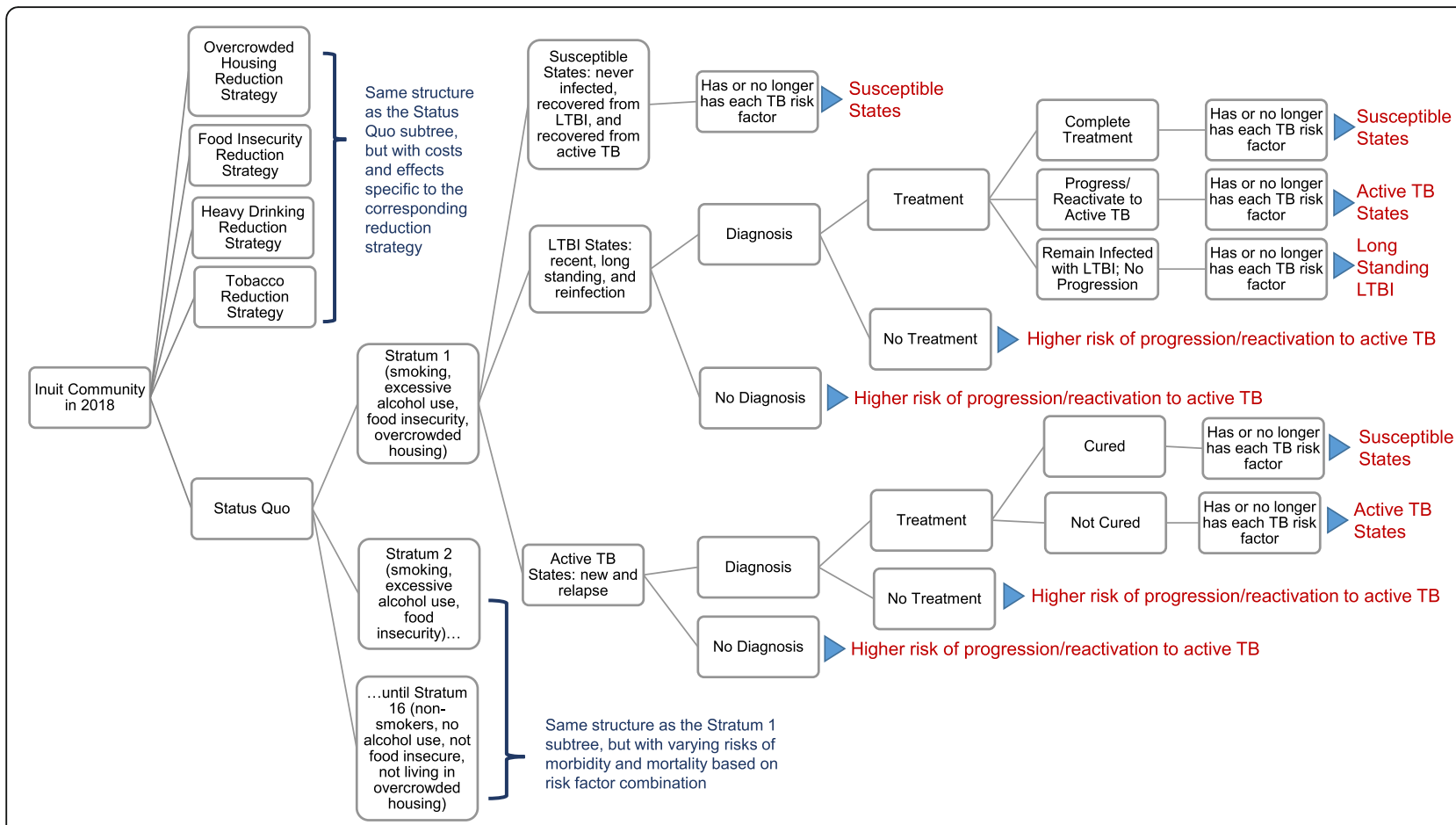

Fig. 1 Simplified schematic of decision analysis model structure. * At the end of each cycle, individuals either continue to have or stop having any of the four TB risk factors (tobacco use, heavy drinking, food insecurity, overcrowded housing). Whether they continue or stop depends on how the prevalence of the factors is changing. For example, if an individual in Stratum 1 (i.e. with all four TB risk factors) is no longer in overcrowded housing by the end of one cycle, they move to Stratum 2 (i.e. having all TB risk factors except overcrowding) at the beginning of the following cycle

(e.g. food insecurity, overcrowded housing). Table 1 shows the specific utility values used to estimate QALYs.

After adjusting pathogenetic parameters for persons with social and behavioral risk factors for TB, all effect estimates for the four risk factors reflected the published literature, and wherever possible these were independent estimates (i.e. adjusted for other potential risk factors). For example, for those who were at increased risk due to smoking, the annual probability for rapid progression following newly acquired TB infection shown in Table 1 (i.e. $0.18 \%$ for those not at risk for any specific TB risk factor) was multiplied by the estimate of effect for active TB conditional on infection $(R R=1.5)$ to give a higher probability of rapid progression for smokers $(0.18 \% \times 1.5=0.27 \%$ for those at risk due to smoking). Similarly, for those at increased risk due to both smoking and heavy drinking, the annual probability of rapid progression following ТВ infection was $0.18 \% \times 1.5 \times 4.2=1.13 \%$.

\section{TB risk factor reduction strategies}

We considered multiple risk reduction strategies. Each strategy selected was highlighted by community members, public health, and academic informants in Nunavut, and wherever appropriate, was a land-based Inuitled intervention. Land-based strategies were those that incorporated the land in their structure, rooted in the notion that the land is a fundamental component of health, wellbeing and culure for Indigenous Peoples [43]. A systematic review of the proximate determinants of TB in Indigenous communities [2] helped inform potential risk reduction strategies. In instances where we were unable to identify strategies implemented in the Arctic, we used information from other relevant settings. In our final short list, we considered only those reduction strategies where information was available on both cost and effect, and which were considered acceptable by informants in Nunavut. Cost and effect data often came from separate reports. A brief summary follows. Detailed descriptions of each of the strategies selected are provided in Additional file 1 - section "Risk factor reduction strategies".

\section{Tobacco reduction strategy}

Our previous analysis addressing tobacco reduction considered several cessation strategies separately, and in combination [23]. A combined strategy consisting of pharmacotherapy coupled with counselling, mass-media campaigns and increased tobacco taxation was found to be the most cost effective approach to reducing tobacco use. We therefore used this combined approach as the 
Table 1 Decision analysis model parameters related to the natural history, epidemiology, treatment of LTBI and TB

\begin{tabular}{|c|c|c|}
\hline ESTIMATE & $\begin{array}{l}\text { PROBABILITY (\%) or } \\
\text { VALUE (RANGE) }\end{array}$ & REFERENCE \\
\hline \multicolumn{3}{|l|}{ Probabilities (once-time percentages) } \\
\hline Probability of completing latent TB infection treatment among those who initiate treatment & 75.6 & {$[28]$} \\
\hline Probability of diagnosing active disease & 90 & Assumption \\
\hline Probability of spontaneous resolution of untreated TB disease & 25 & [29] \\
\hline Probability of relapse after active TB treatment & 1.4 & Dynamic model ${ }^{\mathrm{b}, \mathrm{d}}$ \\
\hline Protective immunity from previous TB disease & 55 & Dynamic model ${ }^{b}$ \\
\hline \multicolumn{3}{|l|}{ Probabilities for those without any of the four specific TB risk factors } \\
\hline Probability of rapid progression following TB infection & $0.18 /$ year $^{a}$ & Dynamic model ${ }^{b}$ \\
\hline Probability of reactivation of longstanding latent TB infection to TB disease & 0.05/year & [30-32] \\
\hline Probability of dying from untreated TB & 7.7/year ${ }^{c}$ & [33] \\
\hline Probability of dying from TB during treatment & $1.7 /$ year ${ }^{\mathrm{c}}$ & [34] \\
\hline \multicolumn{3}{|l|}{ Quality Adjusted Life Years for Latent TB linfectuin and active TB } \\
\hline Utility score for individual with active TB disease (during treatment) & $0.85(0.70-0.90)$ & [35] \\
\hline Utility score for individual with active TB disease (before treatment) & $0.68(0.65-0.72)$ & {$[36]$} \\
\hline Utility score for individual with latent TB infection, (during treatment) & $0.97(0.95-1.00)$ & {$[36]$} \\
\hline Utility score for individual with latent TB infection (before treatment) & 1 & Assumption ${ }^{\mathrm{e}}$ \\
\hline
\end{tabular}

${ }^{a}$ This value is very low because it applies only to those not exposed to any of the four TB risk factors. Taking a weighted average across the 16 strata gives a rapid progression value of $0.8 \% /$ year

${ }^{\mathrm{b} C a l i b r a t e d ~ u s i n g ~ d y n a m i c ~ m o d e l, ~ s e e ~ A d d i t i o n a l ~ f i l e ~} 1$ - section "Calibration details"

'Taking a weighted average of these values over all 16 strata gives values from literature

${ }^{\mathrm{d}}$ Although this is calibrated, its initial value was based on the literature: the probability of relapse following active TB treatment started at 1.5\% [34, 37]

e Individuals with latent TB infection are asymptomatic and are assumed to be otherwise healthy

Table 2 TB risk factor specific multipliers applied to probabilities in decision analysis model

\begin{tabular}{|c|c|c|c|c|}
\hline Outcome & MEASURE of EffecT ${ }^{\mathrm{a}}$ & ESTIMATE $(95 \% \mathrm{Cl})$ & Comparison & Reference \\
\hline \multicolumn{5}{|l|}{ SMOKING } \\
\hline Infection & Relative Risk & $1.9(1.6-2.3)$ & Ever or current smokers vs. never smokers & [11] \\
\hline Active Disease & Relative Risk & $1.5(1.3-1.7)$ & Ever or current smokers vs. never smokers & [12] \\
\hline Death & Relative Risk & $2.6(1.8-3.6)$ & Ever or current smokers vs. never smokers & [11] \\
\hline \multicolumn{5}{|l|}{ HEAVY DRINKING } \\
\hline Infection & Relative Risk & $2.9(1.9-4.6)$ & $\begin{array}{l}\geq 40 \mathrm{~g} \text { alcohol per day and/or alcohol use disorder } \\
\text { vs. }<40 \mathrm{~g} \text { alcohol per day and no alcohol use disorder }\end{array}$ & [38] \\
\hline Active Disease & Relative Risk & $4.2(2.7-6.5)$ & $\begin{array}{l}\geq 40 \mathrm{~g} \text { alcohol per day and/or alcohol use disorder } \\
\text { vs. }<40 \mathrm{~g} \text { alcohol per day and no alcohol use disorder }\end{array}$ & [39] \\
\hline Death & Hazard Ratio & $2.4(1.1-5.3)$ & $\begin{array}{l}\text { Addiction to alcohol } \\
\text { vs. no addiction to alcohol }{ }^{\#}\end{array}$ & [40] \\
\hline \multicolumn{5}{|l|}{ FOOD INSECURITY } \\
\hline Infection & Odds Ratio & $2.1(1.0-4.3)$ & $\begin{array}{l}\text { Inadequate daily fruit/vegetable intake } \\
\text { vs. adequate daily fruit/vegetable intake }\end{array}$ & [16] \\
\hline Active Disease & Odds Ratio & $2.4(1.6-3.1)$ & $\begin{array}{l}\text { People experiencing household food shortage } \\
\text { vs. not experiencing household food shortage }\end{array}$ & [41] \\
\hline \multicolumn{5}{|l|}{ OVERCROWDING } \\
\hline Infection & Relative Risk & $1.5(1.1-2.0)$ & $\begin{array}{l}\text { Houses with }>1 \text { person per room } \\
\text { vs. houses with } \leq 1 \text { person per room }\end{array}$ & {$[20]$} \\
\hline Active Disease & Odds Ratio & $1.3(1.2-1.5)^{c}$ & For every additional 0.2 persons per room & [19] \\
\hline
\end{tabular}

${ }^{a}$ Where possible, we obtained adjusted estimates from each study

"Adequacy of daily fruit and vegetable intake was determined based on North American reference standards for age and sex, assuming individuals had a "typical" level of physical activity

${ }^{c}$ We modified this estimate to reflect the added risk for every additional 1 person per room (we used $1.3^{5}=3.7$ [95 $\left.\% \mathrm{Cl} 2.5-7.6\right]$ ) 
primary tobacco reduction strategy in our current analyses.

\section{Heavy drinking reduction strategy}

The heavy drinking reduction strategy is centred on a land-based healing camp [44]. Such a program currently operates out of the Cambridge Bay Wellness Centre, and is set to expand to two other regions in Nunavut [21]. The strategy assumes a 28-day inpatient camp offered 3 to 4 times per year, with programming focused on both clinical and cultural healing. For our analysis, we assumed the program was scaled up in the three regions (Kitikmeot, Kivalliq and Qikiqtaaluk) by a factor of 5, so as to achieve sufficient population coverage. Costs were scaled up proportionally, based on published budgets [21].

\section{Food insecurity reduction strategy}

We considered a comprehensive approach to reducing food insecurity that incorporated initiatives based in Nunavut and the Northwest Territories. Specifically, we considered as prototype programs the Niqinik Nuatsivik Nunavut Food Bank, the First Nations and Inuit component of the Canada Prenatal Nutrition Program (CPNP) [45], Nunavut's Country Food Distribution Program (CFDP), and a community greenhouse project in Hay River, Northwest Territories in combination [46-49]. Based on the available information, costs were adjusted to reflect full coverage of the food-insecure population (or in the CPNP's case, all food-insecure pregnant women).

\section{Overcrowded housing reduction strategy}

During 2014-2015, there were 210 housing units constructed in 12 communities in Nunavut and 216 housing units in 8 communities in Nunavik (the Inuit homeland within Quebec) [50]. These housing units were a combination of one-, two- and four-bedroom houses and apartments. We used data related to construction of these 426 units to inform the strategy for reducing overcrowded housing.

\section{Effects of mitigation strategies on associated risk factors} The anticipated effect of each mitigation strategy on the associated risk factor is summarized in Table 3. We obtained estimates of effect from the published literature which described the implementation of the selected strategies [50-54]. Additional details regarding the estimate of effect for risk factor reduction strategies are provided in Additional file 1 - Supplemental Table 4.

We assumed that the population that was no longer exposed to a particular risk factor would remain without it for the rest of the simulation. For example, those who were no longer food insecure as the result of the intervention were categorized as food secure for the remaining simulation. For all scenarios we also considered the ongoing background change in risk factor prevalence, in the absence of any specific new reduction strategy. The rate of background change was informed by published literature on risk factors from Nunavut $[6$, $8,9,57-63]$.

\section{Costs}

All costs are expressed in 2018 Canadian dollars and are from the government payer perspective [64].

\section{Costs related to social and behavioural risk factor reduction strategies}

Table 4 summarizes the costs associated with each of the reduction strategies. A more detailed description of costs is available in Supplemental Table 5 within Additional file 1 . Wherever possible, we used reported costs from Nunavut associated with each reduction strategy. When that was not possible, we integrated published costs from comparable settings. For example, tobacco reduction strategy costs reflected a Centers for Disease Control and Prevention (CDC) report and Régie de l'assurance maladie du Québec (RAMQ) data $[65,66]$. Charges to buyers related to tobacco taxation do not represent net costs for government health payers or society as a whole. Costs for the healing camps (alcohol use reduction) were based on a report that outlined their implementation across Nunavut [21]. Costs related to the initiatives included in the food insecurity intervention came from program reports and published budgets from Nunavut and the Northwest Territories [46-49]. Lastly, the housing construction costs came from an Inuit Tapiriit Kanatami (ITK) report [67] outlining a housing strategy across the four Inuit homelands, and the annual maintenance costs reflected information from a Nunavut Housing Commission report [68].

We did not assume that once community members became food secure, they would no longer need the food bank, greenhouse or country food program. As such, those who became food secure as a result of these programs continued to use them and incurred the associated cost. This is in contrast to pharmacotherapy, for example, where the population who quit smoking as a result of this program did not incur subsequent related smoking cessation costs.

\section{TB-related health system costs}

Costs associated with active TB and LTBI management and clinical care are summarized in Table 5. This includes TB-related diagnostic costs, treatment costs, and costs of adverse events associated with $\mathrm{TB}$ medications. The cost of treating active TB also includes transfers to Ottawa for patients requiring complex care, which 


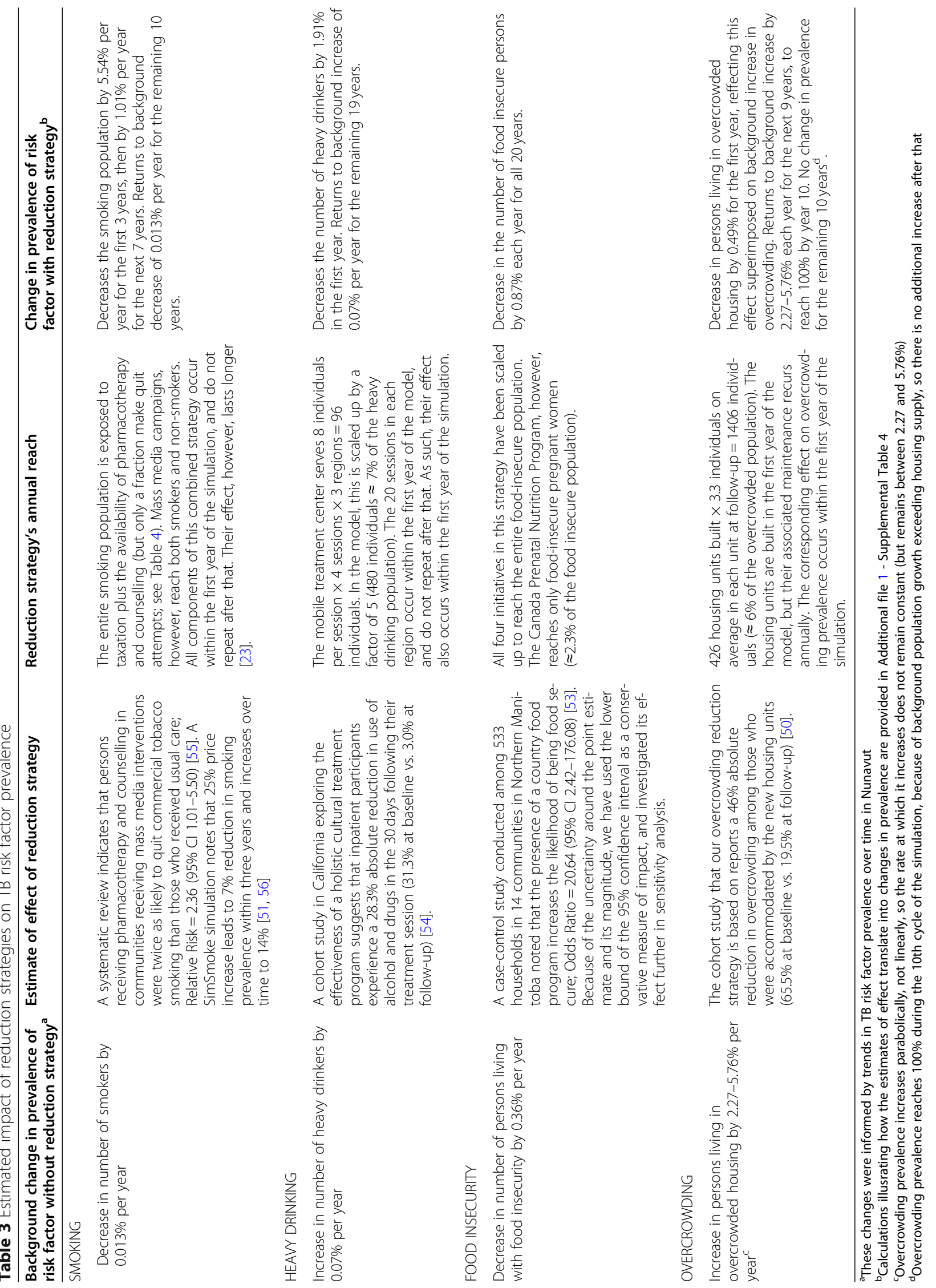


Table 4 Risk factor reduction strategy costs (2018 \$CAD)

\begin{tabular}{|c|c|c|c|}
\hline Strategy & Components & Cost & Reference \\
\hline \multirow[t]{4}{*}{ combined Tobacco Reduction strategy ${ }^{*}$} & (a) Total per-person cost of pharmacotherapy and counselling & $\$ 1749$ & {$[66,69,70]$} \\
\hline & (b) Proportion of smokers who made a quit attempt & $19.8 \%$ & {$[51]$} \\
\hline & (c) Recommended per capita expenditure on mass media campaigns & $\$ 2.10$ & {$[65]$} \\
\hline & $\begin{array}{l}\text { Prorated mean cost of pharmacotherapy, counselling and mass media per } \\
\text { individual smoker }(a \times b)+c \text { : added to all smokers }{ }^{a}\end{array}$ & $\$ 348$ & \\
\hline \multirow[t]{4}{*}{ on the land HEALING CAMP } & (a) Total per-person start-up cost of healing camps & $\$ 1599$ & {$[21]$} \\
\hline & (b) Total per-person annual operating cost of healing camps & $\$ 37,444$ & {$[21]$} \\
\hline & (c) Proportion of heavy drinking population participating in healing camp & $7 \%$ & {$[21]$} \\
\hline & $\begin{array}{l}\text { Prorated mean cost of healing camps per individual heavy drinker } \\
(a+b) \times c \text { : added to all heavy drinkers }\end{array}$ & $\$ 2695$ & \\
\hline \multirow[t]{6}{*}{ combined food insecurity reduction strategy } & (a) Total per-person cost for Niqinik Nuatsivik Nunavut Food Bank & $\$ 168$ & {$[46]$} \\
\hline & (b) Total per-person cost for Canadian Prenatal Nutrition Program & $\$ 1481$ & {$[47]$} \\
\hline & (c) Pregnant women as a proportion of the food insecure population & $2.3 \%$ & {$[71]$} \\
\hline & (d) Total per-person cost for Country Food Distribution Program & $\$ 412$ & {$[48]$} \\
\hline & (e) Total per-person cost for community greenhouse project & $\$ 11$ & [49] \\
\hline & $\begin{array}{l}\text { Prorated mean per person cost of reduction strategy per food insecure individual } \\
a+(b \times c)+d+e: \text { added to all food insecure individuals }\end{array}$ & $\$ 625$ & \\
\hline \multirow[t]{4}{*}{ Housing construction } & (a) Total per-person cost of building 426 new housing units & $\$ 151,494$ & {$[67,68]$} \\
\hline & (b) Total per-person cost of maintaining 426 housing unit annually & $\$ 2530$ & \\
\hline & (c) Proportion of population in crowded housing moving to a new house & $6 \%$ & {$[50]$} \\
\hline & $\begin{array}{l}\text { Prorated mean per person cost per individual living in overcrowded housing } \\
(a+b) \times c \text { : added to all individuals living in overcrowded housing }\end{array}$ & $\$ 9149$ & \\
\hline
\end{tabular}

${ }^{a}$ Mass media costs also applied to non-smokers, as exposure to mass media campaigns is not exclusive to smokers

occurs in approximately $4 \%$ of persons with active TB [35, 72]. TB-related health system costs were obtained from published sources from Nunavut, where available.

\section{Sensitivity and scenario analysis}

Tornado diagrams were used to identify the most influential model parameters for each strategy. Additional sensitivity analyses focused on those parameters. In the

Table 5 TB-related health system costs in Nunavut (2018 \$CAD)

\begin{tabular}{lll}
\hline Components & Cost & Reference \\
\hline Tuberculin skin test & $\$ 19$ & {$[73]$} \\
9-month regimen of isoniazid & $\$ 186$ & {$[66]$} \\
Major adverse reaction to isoniazid & $\$ 15,269$ & {$[73]$} \\
Chest X-ray & $\$ 70$ & {$[74]$} \\
$\begin{array}{l}\text { Three sputum samples analysis } \\
\text { (when results are negative) }\end{array}$ & $\$ 30$ & {$[72]$} \\
$\begin{array}{l}\text { Three sputum samples analysis } \\
\text { (when results are positive; includes PCR probe) }\end{array}$ & $\$ 83$ & {$[72]$} \\
$\begin{array}{l}\text { Spontaneous sputum production per sample } \\
\text { Sputum induction for 3 samples }\end{array}$ & $\$ 3.60$ & {$[35]$} \\
$\begin{array}{l}\text { Xpert } \\
\text { STB/RIF test for one individual (1 sample) }\end{array}$ & $\$ 137$ & {$[35]$} \\
$\begin{array}{l}\text { Standard 6-month active TB medication } \\
\text { regimen (including Vitamin B6) }\end{array}$ & $\$ 655$ & {$[66]$} \\
\hline PCR polymeras & & \\
\hline
\end{tabular}

$P C R$ polymerase chain reaction case of the food insecurity reduction strategy, we started from an assumed odds ratio of 2.42 for becoming food secure, as described in Table 3 [53]. This was a much more conservative point estimate than in the study by Thompson and colleagues. However, we considered even more limited impact (odds ratio as low as 1.35) as well as up to 5.5 , so as to remain symmetric on the logarithmic scale. Because of the marked uncertainty about the effect of programs in improving food security, we focused primarily on identifying thresholds where the food security intervention produced reductions in TB incidence similar to those afforded by programs targeting other risk factors. We also considered various combinations of the four strategies.

The Inuit Nunangat Housing Strategy estimates a current gap of 3500 housing units for Nunavut without accounting for population growth [67]. This strategy advocates for housing construction and improvement in housing conditions across Inuit Nunangat. As such, we considered additional scenarios where more than 426 houses were to be built in the overcrowding reduction strategy. We continued to assume that an average of 3.3 individuals would be accommodated in each house [50].

Probabilistic sensitivity analysis (PSA) was conducted by varying parameter estimates over their distributions (see Additional file 1 - Supplemental Table 5) and 
running 10,000 simulations to generate $95 \%$ uncertainty ranges (UR) for all model outputs.

\section{Results}

\section{Base case}

Compared to the status quo scenario with no new interventions directed at any of the four risk factors, the tobacco reduction strategy reduced TB incidence by $5.5 \%$ (95\% UR: $2.6-11 \%$ ) over 20 years. The reduction strategy for food insecurity reduced TB incidence by 1.8\% (95\% UR: $0.5-3.1 \%)$, the heavy drinking reduction strategy reduced it by $0.7 \%$ (95\% UR: $0.4-0.9 \%$ ), and the overcrowding reduction strategy at current scale reduced it by $1 \%$ (95\% UR: $0.6-1.3 \%$ ). In addition, the tobacco reduction strategy had the largest impact on TB-related deaths, reducing them by $13.4 \%$ (95\% UR: 6.9-25.8\%) over 20 years, and the largest effect on QALYs, which increased by 3.1 per 1000 persons (95\% UR: $1.2-8.9$ ) over 20 years relative to the status quo. Results are shown in Table 6.

Incremental cost-effectiveness ratios (ICERs) comparing each strategy to the preceding strategy are shown in Table 7.

The tobacco reduction strategy was estimated to cost just under $\$ 50,000$ per QALY gained. Strategies targeting each of the other risk factors alone were dominated, i.e. more expensive but less effective. Strategies involving combinations of interventions were much more expensive relative to health gains. Hence the combination of all four strategies had the highest anticipated reduction in TB incidence, but was also the most expensive, with an estimated incremental cost of nearly \$14 million per QALY gained or nearly $\$ 18$ million per TB case prevented. Combining the tobacco reduction and food insecurity reduction strategies yielded a similar reduction in TB incidence, but at a much lower cost. Specifically, its total cost was $68.6 \%$ lower (95\% UR: $64.8-71.2 \%$ ) and
TB incidence only $1.6 \%$ higher (95\% UR: $1.1-2.1 \%$ ) when compared to the combination of all four strategies.

Table 8 shows the breakdown of costs, between the reduction strategies and the TB- related health system costs. While all strategies were associated with some savings on TB-related health system costs, the costs for each strategy itself consistently outweighed any savings.

\section{Scenario and sensitivity analyses}

Results of scenario analyses considering varying levels of housing construction are shown in Table 9. Meeting the 3500 units housing gap in Nunavut would further reduce TB incidence and related deaths by $6.9 \%$ over 20 years compared to the more limited scale of overcrowding reduction assumed in the base case scenario. Per-person costs and incremental cost-effectiveness ratios remain largely unchanged.

Tornado diagrams (Additional file 1 - Supplemental Figs. 4-9) showed that predicted costs associated with each reduction strategy were most affected by the parameter representing the relative risk of progressing to active disease following infection for individuals living in overcrowded housing compared to individuals in noncrowded housing, as well as by the cost of hospitalisation.

When the food insecurity reduction strategies were assumed to reduce food insecurity by a factor of greater than 5.5 fold, they became more effective at reducing TB incidence than the tobacco reduction strategy. Despite becoming more effective for reducing incidence, the food insecurity reduction strategy was more expensive than the tobacco reduction strategy and was associated with higher relative TB mortality. This is because tobacco use is directly associated with increased TB case fatality, so that reduced tobacco use leads to lower case fatality. Further sensitivity analysis results are presented in Additional file 1 - section "Sensitivity analysis".

Table 6 Projected costs and health outcomes per 1000 persons over 20 years

\begin{tabular}{|c|c|c|c|c|}
\hline Outcomes per 1000 persons (95\% UR) & Cost & TB Incidence & TB Deaths & QALYs \\
\hline Status Quo & $\begin{array}{l}\$ 1,199,205(\$ 765,946 \rightarrow \$ 1,883 \\
900)\end{array}$ & $\begin{array}{l}29.12(19.06 \rightarrow \\
43.21)\end{array}$ & $\begin{array}{l}2.76(1.32 \rightarrow \\
6.25)\end{array}$ & $\begin{array}{l}15,001.86(14,968.20 \rightarrow \\
15,014.70)\end{array}$ \\
\hline Tobacco Reduction Strategy & $\begin{array}{l}\$ 1,353,274(\$ 946,333 \rightarrow \$ 1,994 \\
712)\end{array}$ & $\begin{array}{l}27.51(18.13 \rightarrow \\
40.40)\end{array}$ & $\begin{array}{l}2.39(1.15 \rightarrow \\
5.35)\end{array}$ & $\begin{array}{l}15,004.96(14,975.35 \rightarrow \\
15,016.31)\end{array}$ \\
\hline Heavy Drinking Reduction Strategy & $\begin{array}{l}\$ 1,680,078(\$ 1,250,339 \rightarrow \$ 2 \\
359,473)\end{array}$ & $\begin{array}{l}28.92(18.96 \rightarrow \\
42.83)\end{array}$ & $\begin{array}{l}2.73(1.31 \rightarrow \\
6.16)\end{array}$ & $\begin{array}{l}15,002.17(14,969.09 \rightarrow \\
15,014.83)\end{array}$ \\
\hline Food Insecurity Reduction Strategy & $\begin{array}{l}\$ 3,300,445(\$ 2,876,803 \rightarrow \$ 3 \\
974,764)\end{array}$ & $\begin{array}{l}28.58(18.75 \rightarrow \\
42.26)\end{array}$ & $\begin{array}{l}2.71(1.30 \rightarrow \\
6.13)\end{array}$ & $\begin{array}{l}15,002.32(14,969.19 \rightarrow \\
15,014.94)\end{array}$ \\
\hline $\begin{array}{l}\text { Food Insecurity Reduction Strategy and Tobacco } \\
\text { Reduction Strategy }\end{array}$ & $\begin{array}{l}\$ 3,456,071(\$ 3,056,024 \rightarrow \$ 4 \\
081,059)\end{array}$ & $\begin{array}{l}27.02(17.88 \rightarrow \\
39.60)\end{array}$ & $\begin{array}{l}2.35(1.13 \rightarrow \\
5.25)\end{array}$ & $\begin{array}{l}15,005.36(14,976.11 \rightarrow \\
15,016.51)\end{array}$ \\
\hline Overcrowding Reduction Strategy & $\begin{array}{l}\$ 8,282,029(\$ 7,854,241 \rightarrow \$ 8 \\
955,843)\end{array}$ & $\begin{array}{l}28.84(18.93 \rightarrow \\
42.73)\end{array}$ & $\begin{array}{l}2.74(1.31 \rightarrow \\
6.19)\end{array}$ & $\begin{array}{l}15,002.18(14,968.91 \rightarrow \\
15,014.86)\end{array}$ \\
\hline All Four Reduction Strategies in Combination & $\begin{array}{l}\$ 11,021,792(\$ 10,630,433 \rightarrow \\
\$ 11,635,312)\end{array}$ & $\begin{array}{l}26.59(17.67 \rightarrow \\
38.87)\end{array}$ & $\begin{array}{l}2.31(1.12 \rightarrow \\
5.12)\end{array}$ & $\begin{array}{l}15,005.90(14,977.39 \rightarrow \\
15,016.78)\end{array}$ \\
\hline
\end{tabular}




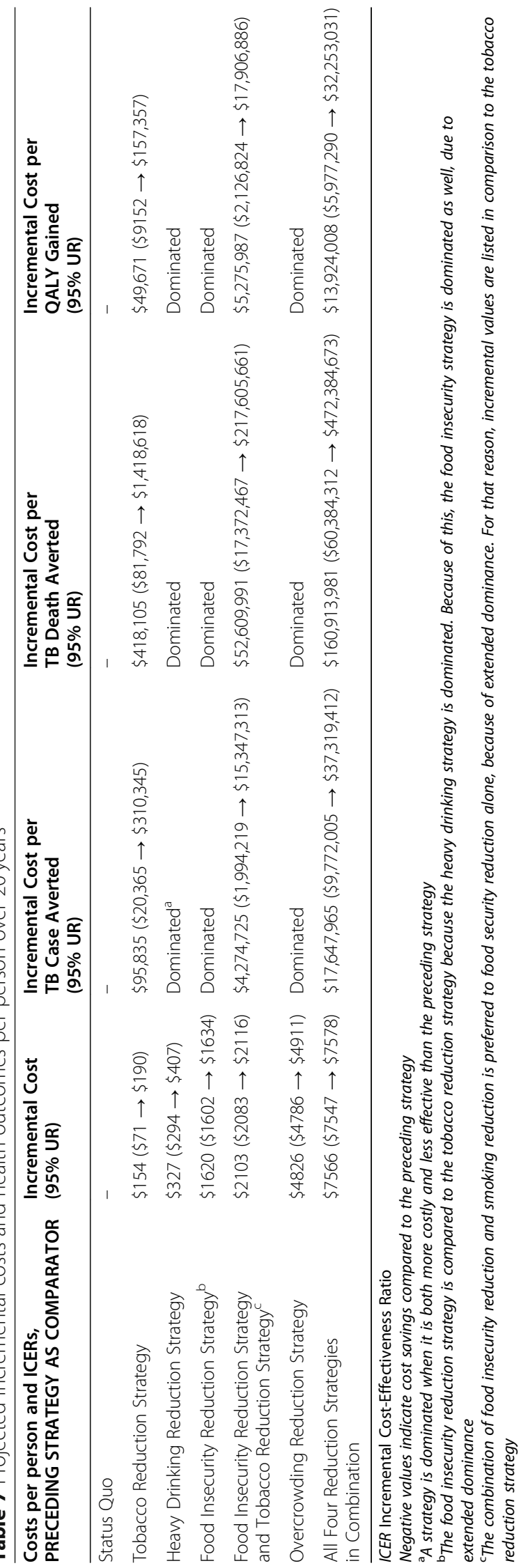


Table 8 Projected health system and intervention costs per 1000 persons over 20 years

\begin{tabular}{lllll}
\hline Outcomes per $\mathbf{1 0 0 0}$ persons & Total Cost & Intervention Cost & TB-Related Health System Cost & $\begin{array}{l}\text { TB-Related Health System Savings } \\
\text { Compared to Status Quo }^{\mathbf{a}}\end{array}$ \\
\hline Status Quo & $\$ 1,199,205$ & $\$ 0$ & $\$ 1,199,205$ & - \\
Tobacco Reduction Strategy & $\$ 1,353,274$ & $\$ 209,829$ & $\$ 1,143,444$ & $\$ 55,761$ \\
Heavy Drinking Reduction Strategy & $\$ 1,680,078$ & $\$ 487,941$ & $\$ 1,192,137$ & $\$ 7068$ \\
Food Insecurity Reduction Strategy & $\$ 3,300,445$ & $\$ 2,119,885$ & $\$ 1,180,560$ & $\$ 18,646$ \\
Overcrowding Reduction Strategy & $\$ 8,282,029$ & $\$ 7,092,984$ & $\$ 1,189,045$ & $\$ 10,161$ \\
\hline
\end{tabular}

${ }^{a}$ calculated as TB-related health system cost in status quo scenario - TB-related health system cost in intervention scenario

\section{Discussion}

Our analysis identified the tobacco reduction strategy as least costly and most effective in reducing TB morbidity and mortality. The strategies for heavy drinking reduction and food security were also beneficial, albeit at higher cost. The population-level impact of the housing intervention was constrained by limited reach and high cost at current scale. However, this intervention has potential to reduce TB morbidity and mortality substantially when scaled up and provides vital benefits, including improved mental health, education and food security $[75,76]$. Similarly, the land-based healing camp reached only a fraction of the heavy-drinking population at current scale, but provides great benefit to those individuals. Both interventions may be scaled up to meet a community's needs, but their costs would increase proportionally, so the per-person cost would remain similar.

Overall, the parameter representing the relative risk of progression to active disease among people in crowded homes compared to non-crowded homes was the most influential in driving costs and effectiveness. This may be because of the estimate's magnitude, as well as the rise in overcrowding prevalence throughout the model's analytic horizon.

The strategies for food security and reduction of heavy drinking both draw explicitly on the community's culture, practices and strengths. However, these strategies also depend on materials from the South, e.g. construction and maintenance of community freezers, certain foods for the food banks, and building supplies for onthe-land healing camps. Transport of materials from the South has substantial cost implications, and is a driver for the high cost of these strategies, as well as the strategy to reduce overcrowding.

Although $\$ 50,000$ per quality adjusted life year has been a frequent benchmark, Canadian guidelines do not recommend any specific threshold in assessing cost-effectiveness [77], while the United Kingdom and United States guidelines generally use thresholds of $£ 50,000 \mathrm{GBP}$ and $\$ 100,000$ USD, respectively [77, 78]. Policy and program decisions should reflect not only cost-effectiveness estimates, but feasibility and cultural acceptability. Where possible, we based our risk factor reduction strategies on initiatives that already exist in remote settings to illustrate their feasibility.

It is important to consider some limitations of our study. We did not address other improvements in health related to mitigation of tobacco and alcohol use, food insecurity, and overcrowded housing. We did not consider how a change in prevalence of one TB risk factor might affect the prevalence of others, or whether the effect of certain risk factors was dose-dependent (i.e. how much an individual's risk of TB would change when they used more tobacco). Where information on costs and effects of the reduction strategies selected was not available from Nunavut, we used information from other settings, which were not always specific to Inuit communities.

In some cases, our results reflect limited data with imprecise measures. Most importantly, a study conducted in 14 communities in Northern Manitoba found that persons in communities with a country food program were 20 times more likely to be food secure than in communities without such a program [53], but the confidence interval was extremely wide. We considered the lower bound of this interval as a conservative estimate of

Table 9 Projected overcrowding reduction strategy outcomes per 1000 persons over 20 years

\begin{tabular}{|c|c|c|c|c|c|}
\hline $\begin{array}{l}\text { Number of Housing } \\
\text { Units Built }\end{array}$ & $\begin{array}{l}\text { Estimated Number of } \\
\text { Individuals Accommodated }\end{array}$ & Cost & TB Incidence & TB Deaths & $\begin{array}{l}\text { Quality Adjusted } \\
\text { Life Years }\end{array}$ \\
\hline 426 & 1406 & $\$ 8,282,029$ & 28.84 & 2.74 & $15,002.18$ \\
\hline 1500 & 4950 & $\$ 17,736,070$ & 28.47 & 2.70 & $15,002.61$ \\
\hline $3500^{\mathrm{a}}$ & 11,550 & $\$ 57,714,176$ & 26.84 & 2.55 & $15,004.47$ \\
\hline 7000 & $23,100^{b}$ & $\$ 110,409,791$ & 24.58 & 2.34 & $15,007.08$ \\
\hline 10,000 & 33,000 & $\$ 152,537,566$ & 22.60 & 2.15 & $15,009.31$ \\
\hline
\end{tabular}

${ }^{a}$ Number of housing units needed to close the housing gap according to the Inuit Nunangat Housing Strategy (INHS 2019)

${ }^{\mathrm{b}}$ Approximately equal to the number of individuals living in overcrowded housing in Nunavut in 2018 
effect in our base case scenario due to the lack of other published information. As such, more data are needed with respect to the precise impact of such reduction strategies, especially because food insecurity is a prevalent issue.

Nonetheless, there is good reason to expect that investments that successfully mitigate these risk factors will reduce $\mathrm{TB}$ morbidity and mortality. In this sense, they will complement recent efforts to improve diagnostic capacity and prevention [79]. The relative isolation of many Indigenous communities highlights the role of preventive strategies that build on local resources. In Indigenous communities worldwide, building local capacity is key to addressing social and behavioural risk factors. Some key examples are initiatives that address tobacco use, heavy drinking and diabetes in Aboriginal peoples and Torres Strait Islanders in Australia [80-83].

Few studies from Indigenous settings have explored cost-effectiveness of community based interventions that target social and behavioural determinants of health. One study highlighted health gains associated with a community-based intervention to reduce diabetes and cardiovascular disease in a remote region of Western Australia [84]. Another Australian report suggested that price discounts to encourage healthy eating in remote Indigenous communities were in fact associated with poorer population health; instead, more holistic, culturally appropriate strategies were encouraged [85]. More generally, economic evaluations of health interventions in Indigenous settings have underscored the importance of leveraging local capacity and advocating community ownership [86]. These are also essential elements of $\mathrm{TB}$ prevention and care in non-Indigenous settings.

Economic analyses from non-Indigenous settings have emphasized the importance of addressing social and behavioural determinants of health. One report highlighted the cost-effectiveness of screening and brief interventions for excess alcohol use in European countries [87], while another underlined the cost-effectiveness of repeated tobacco cessation counselling in the United States [88]. Financial protection strategies to mitigate TB's downstream social impacts have been identified as essential components of person-centred care [89]. Clearly, social and behavioural risk factors for TB will require concerted action if we are to meet key national and global TB reduction targets [2, 41, 90-93].

The history of TB in Canada's North is tightly linked to colonization and colonial policies [3, 94, 95]. Hence it is all the more important to prioritize strategies led by Inuit community members, and based in Inuit culture and the land. The launch of the Canadian Tuberculosis Task Force to address TB [95] in Inuit communities has emphasized the significance of local partnerships to ensure such strategies are culturally appropriate, sustainable, and speak to the Inuit experience.

\section{Conclusion}

Strategies that reduce commercial tobacco use will likely lead to modest improvement in tuberculosis morbidity and mortality in Canada's North, and may be reasonably cost-effective. From the TB perspective, strategies to address food insecurity will have less impact at higher cost, although these bring other important health benefits. Similarly, strategies that address excess alcohol use and overcrowding will have a limited impact on TB-related outcomes at current scale. Their benefits will be more substantial with scale up. Strategies that address alcohol use and overcrowding will likely also have meaningful impact beyond TB, including improved mental health and educational attainment. These findings will also be relevant to other Indigenous and non-Indigenous communities and settings, where these risk factors and $\mathrm{TB}$ are co-prevalent.

\section{Supplementary Information}

The online version contains supplementary material available at https://doi. org/10.1186/s12889-021-10187-z.

Additional file 1:. Supplemental methods and results. Contains additional details of dynamic model, decision analysis model, sensitivity analyses, dynamic model equations

\begin{abstract}
Abbreviations
CDC: Centers for Disease Control and Prevention; CFDP: Country Food Distribution Program; Cl: Confidence interval; CPNP: Canada Prenatal Nutrition Program; HR: Hazard ratio; ICER: Incremental cost-effectiveness ratio; INH: Isoniazid; ITK: Inuit Tapiriit Kanatami; LTBI: Latent tuberculosis infection; OR: Odds ratio; PCR: Polymerase chain reaction; PSA: Probabilistic sensitivity analysis; QALY: Quality adjusted life year; RAMQ: Régie de l'assurance maladie du Québec; RR: Relative risk; UR: Uncertainty range
\end{abstract}

\section{Acknowledgments}

The authors would like to acknowledge Dr. Jordan Sugarman for his assistance with initial literature and costing reviews. In addition, we wish to acknowledge the key guidance and input of the TAIMA-TB Steering Committee, Janet Stafford, Dr. Mylène Riva, and Deborah Van Dyk.

Ethics approval and consent for participation

Not required as this research involved modeling based on existing, publicly available data and there were no individual participants.

\section{Authors' contributions}

$\mathrm{AU}$ developed models, obtained cost inputs, conducted analyses, and drafted the manuscript. OO helped design the study, contributed to model development, reviewed results, and provided critical input into this manuscript. NPN helped develop models, obtained cost inputs, supported analyses, and provided critical input into this manuscript. DN'D helped develop models, reviewed results, and provided critical input into this manuscript. GA helped design the study, contributed to model development including key clinical, epidemiologic, and social parameters, reviewed results, and provided critical input into this manuscript. KS helped design the study, supervised all aspect of its development and the analyses, and provided extensive revisions and critical input into this manuscript. The author(s) read and approved the final manuscript. 


\section{Funding}

This research was funded by the Canadian Institutes of Health Research and its Institute for Indigenous Peoples' Health, via grants 126659 and 136798.

\section{Availability of data and materials}

All models and relevant data inputs are available upon request to the corresponding author.

\section{Consent for publication}

Not applicable.

\section{Competing interests}

All authors declare that they have no competing interests.

\section{Author details}

${ }^{1}$ Montreal Chest Institute, Montreal, Quebec, Canada. ${ }^{2}$ Respiratory Epidemiology and Clinical Research Unit, Centre for Outcomes Research and Evaluation, Research Institute of McGill University Health Centre, Montreal, Quebec, Canada. ${ }^{3}$ McGill International Tuberculosis Centre, 1001 boulevard Décarie, Room D05.2511, Montréal, Québec H4A 3J1, Canada. ${ }^{4}$ Department of Epidemiology, Biostatistics and Occupational Health, McGill University, Montreal, Quebec, Canada. ${ }^{5}$ The Ottawa Hospital Research Institute, Department of Medicine, Division of Respirology, The Ottawa Hospital, University of Ottawa, Ottawa, Ontario, Canada.

Received: 18 May 2020 Accepted: 6 January 2021

\section{Published online: 03 February 2021}

\section{References}

1. Global tuberculosis report 2020. Geneva: World Health Organization; 2020 Licence: CC BY-NC-SA 3.0 IGO. https://apps.who.int/iris/bitstream/handle/1 0665/336069/9789240013131-eng.pdf

2. Cormier M, Schwartzman K, N'Diaye DS, Boone CE, dos Santos AM, Gaspar J et al. Proximate determinants of tuberculosis in indigenous peoples worldwide: a systematic review. Lancet Glob Health. 2019;7(10):E68-80. https://doi.org/10.1016/S2214-109X(18)30435-2.

3. Dehghani K, Lan Z, Li P, Michelsen SW, Waites S, Benedetti A, et al. Determinants of tuberculosis trends in six Indigenous populations of the USA, Canada, and Greenland from 1960 to 2014: a population-based study. Lancet Public Health. 2018. https://doi.org/10.1016/S2468-2667(18)30002-1. http://www.thelancet.com/pdfs/journals/lanpub/PIIS2468-2667(18)30002-1. pdf.

4. Møller H. Tuberculosis and colonialism: current tales about tuberculosis and colonialism in Nunavut. J Aborig Health. 2010;6(1). https://journals.uvic.ca/ index.php/ijih/article/view/12344.

5. LaFreniere M, Hussain H, He N, McGuire M. Tuberculosis in Canada: 2017. Can Commun Dis Rep. 2019;45(2/3):68-74. https://doi.org/10.14745/ccdr.v45i23a04.

6. Statistics Canada. Table 13-10-0451-01. Health indicators, annual estimates, 2003-2014. https://doi.org/10.25318/1310045101-eng.

7. Nunavut Liquor Act Review Task Force. A New Approach: Halting the Harm. Final Report and Recommendations: North Sky Consulting Group Ltd; 2012. https://www.gov.nu.ca/sites/default/files/files/Finance/NLCAnnualReports/ Halting_the_Harm_Final_.pdf

8. Arriagada P. Food insecurity among Inuit living in Inuit Nunangat. Insights on Canadian Society: Statistics Canada Catalogue no. 75-006-X; 2017. https://www150.statcan.gc.ca/n1/en/pub/75-006-x/2017001/article/14774eng.pdf?st=ls91FeEt

9. Statistics Canada. Nunavut [Territory] and Canada [Country] (table). Census Profile. Ottawa: 2016 census. Statistics Canada catalogue no. 98-316X2016001; 2017. Released November 29, 2017. Report no

10. Roshanafshar S, Hawkins E. Food insecurity in Canada. Statistics Canada 2015; https://www.feedopportunity.com/wp-content/uploads/2016/11/StatsCan-Food-Insecurity-Report.pdf.

11. Lin $\mathrm{H}-\mathrm{H}$, Ezzati M, Murray M. Tobacco smoke, indoor air pollution and tuberculosis: a systematic review and meta-analysis. PLoS Med. 2007;4(1):e20 https://www.ncbi.nlm.nih.gov/pmc/articles/PMC1769410/pdf/pmed.0040020.pdf.

12. Lin $\mathrm{H}-\mathrm{H}$, Murray $M$, Cohen T, Colijn C, Ezzati M. Effects of smoking and solidfuel use on COPD, lung cancer, and tuberculosis in China: a time-based, multiple risk factor, modelling study. Lancet. 2008;372(9648):1473-83.

13. Sopori M. Effects of cigarette smoke on the immune system. Nature. 2002; 2(5):372-7.
14. Rehm J, Samokhvalov AV, Neuman MG, Room R, Parry C, Lönnroth K, et al. The association between alcohol use, alcohol use disorders and tuberculosis (TB). A systematic review. BMC Public Health. 2009;9(1):450 https:// bmcpublichealth.biomedcentral.com/track/pdf/10.1186/1471-2458-9-450.

15. Myers B, Bouton TC, Ragan EJ, White LF, Mcllleron H, Theron D, et al. Impact of alcohol consumption on tuberculosis treatment outcomes: a prospective longitudinal cohort study protocol. BMC Infect Dis. 2018;18(1):488 https:// bmcinfectdis.biomedcentral.com/track/pdf/10.1186/s12879-018-3396-y.

16. Fox GJ, Lee RS, Lucas M, Khan FA, Proulx JF, Hornby K, et al. Inadequate diet is associated with acquiring mycobacterium tuberculosis infection in an Inuit community: a case-control study. Ann Am Thorac Soc. 2015:12(8): 1153-62 https://www.atsjournals.org/doi/full/10.1513/AnnalsATS.201503-156 OC?url_ver=Z39.88-2003\&rfr_id=ori\%3Arid\%3Acrossref.org\&rfr_dat=Cr pub\%3Dpubmed\#readcube-epdf

17. Balinda IG, Sugrue DD, Ivers LC. More Than Malnutrition: A Review of the Relationship Between Food Insecurity and Tuberculosis. Open Forum Infect Dis. 2019;6(4):ofz102 https://www.ncbi.nlm.nih.gov/pmc/articles/PMC6441 779/pdf/ofz102.pdf.

18. Canadian Tuberculosis Committee. Housing conditions that serve as risk factors for tuberculosis infection and disease. An Advisory Committee Statement (ACS). Can Commun Dis Rep. 2007;33(ACS-9):1-13 https://www. canada.ca/content/dam/phac-aspc/migration/phac-aspc/publicat/ccdr-rmtc/ 07pdf/acs33-09.pdf.

19. Khan FA, Fox GJ, Lee RS, Riva M, Benedetti A, Proulx JF, et al. Housing and tuberculosis in an Inuit village in northern Quebec: a case-control study. CMAJ Open. 2016:4(3):E496-506 https://www.ncbi.nlm.nih.gov/pmc/articles/ PMC5047805/pdf/cmajo.20160049.pdf.

20. Kilabuk E, Momoli F, Mallick R, Van Dyk D, Pease C, Zwerling A, et al. Social determinants of health among residential areas with a high tuberculosis incidence in a remote Inuit community. J Epidemiol Community Health 2019;73(5):401-6 https://jech.bmj.com/content/jech/73/5/401.full.pdf.

21. NVision Insight Group Inc. Summary Report: Addictions and Trauma Treatment in Nunavut. Government of Nunavut. 2018. https://www.gov.nu. $\mathrm{ca} /$ sites/default/files/gn_att_executive_summary_summary_report_-_final_english.pdf

22. NUNAVUT DEPARTMENT OF HEALTH Nunavut TB Manual 2017: NUNAVUT DEPARTMENT OF HEALTH; 2017. https://www.gov.nu.ca/sites/default/files/ nunavut_tb_manual_2017.pdf.

23. N'Diaye DS, Nsengiyumva NP, Uppal A, Oxlade O, Alvarez GG, Schwartzman $K$. The potential impact and cost-effectiveness of tobacco reduction strategies for tuberculosis prevention in Canadian Inuit communities. BMC Med. 2019;17(26). https://bmcmedicine.biomedcentral.com/track/pdf/10.11 86/s12916-019-1261-5.

24. Statistics Canada. Age distribution and median age of Inuit by area of residence - Inuit Nunangat, Canada, 2011. Ottawa: 2011 March 29, 2016. Report No.

25. Statistics Canada. Nunavut, Inuit region, Nunavut (Code 640004) (table) National Household Survey (NHS) Aboriginal Population Profile. Ottawa: 2013 November 13, 2013. Report No.

26. Statistics Canada. Nunavik, Inuit region, Quebec (Code 640002) (table). National Household Survey (NHS) Aboriginal Population Profile. Ottawa: 2013 November 13, 2013. Report No.

27. Baltussen RM, Adam T, Tan-Torres Edejer T, Hutubessy RC, Acharya A, Evans DB, Murray CJ, World Health Organization. Making choices in health: WHO guide to cost-effectiveness analysis. World Health Organization; 2003. https://www.who.int/choice/publications/p_2003_generalised_cea.pdf

28. Pease C, Zwerling A, Mallick R, Patterson M, Demaio P, Finn S, Allen J, Van Dyk D, Alvarez GG. The latent tuberculosis infection cascade of care in Iqaluit, Nunavut, 2012-2016. BMC infectious diseases. 2019;19(1):890. https:// link.springer.com/content/pdf/10.1186/s12879-019-4557-3.pdf.

29. Grzybowski S, Enarson DA. The fate of cases of pulmonary tuberculosis under various treatment programmes. Bull IUAT. 1978;53(2):70-5.

30. Comstock GW, Edwards LB, Livesay VT. Tuberculosis morbidity in the US Navy: its distribution and decline 1, 2. Am Rev Respir Dis. 1974;110(5):572-80.

31. Nolan CM, Elarth AM. Tuberculosis in a cohort of Southeast Asian refugees. Am Rev Respir Dis. 1988;137:805-9.

32. Behr MA, Edelstein PH, Ramakrishnan L. Revisiting the timetable of tuberculosis. BMJ. 2018;362:k2738. https://www.bmj.com/content/bmj/362/ bmj.k2738.full.pdf.

33. Tiemersma EW, van der Werf MJ, Borgdorff MW, Williams BG, Nagelkerke NJ. Natural history of tuberculosis: duration and fatality of untreated pulmonary 
tuberculosis in HIV negative patients: a systematic review. PloS one. 2011; 6(4):e17601. https://www.ncbi.n/m.nih.gov/pmc/articles/PMC3070694/pdf/ pone.0017601.pdf.

34. Oxlade O, Sugarman J, Alvarez GG, Pai M, Schwartzman K. Xpert ${ }^{\circledR}$ MTB/RIF for the diagnosis of tuberculosis in a remote Arctic setting: Impact on cost and time to treatment initiation. PloS one. 2016;11(3):e0150119. https:/www.ncbi.nlm.nih.gov/ pmc/articles/PMC4798714/pdf/pone.0150119.pdf.

35. Bauer M, Ahmed S, Benedetti A, Greenaway C, Lalli M, Leavens A, et al. Health-related quality of life and tuberculosis: a longitudinal cohort study. Health Qual Life Outcomes. 2015;13(1):65.

36. Guo N, Marra CA, Marra F, Moadebi S, Elwood RK, FitzGerald JM. Health state utilities in latent and active tuberculosis. Value in health. 2008;11(7):1154-61.

37. Grzybowski S. Drugs are not enough: failure of short-course chemotherapy in a district in India. Tuber Lung Dis. 1993;74(3):145-6.

38. Lönnroth $\mathrm{K}$, Williams, BG, Stadlin S, Jaramillo E, Dye C. Alcohol use as a risk factor for tuberculosis - a systematic review. BMC Public Health. 2008;8:289. https:// bmcpublichealth.biomedcentral.com/track/pdf/10.1186/1471-2458-8-289.

39. Rehm J, Samokhvalov AV, Neuman MG, Room R, Parry C, Lönnroth K, Patra J, Poznyak V, Popova S. The association between alcohol use, alcohol use disorders and tuberculosis (TB). A systematic review. BMC Public Health. 2009;9(1):450. https:// link.springer.com/content/pdf/10.1186/1471-2458-9-450.pdf.

40. Borgdorff MW, Veen J, Kalisvaart NA, Nagelkerke N. Mortality among tuberculosis patients in The Netherlands in the period 1993-1995. Eur Respir J. 1998;11(4):816-20. https://erj.ersjournals.com/content/erj/11/4/816.full.pdf.

41. Berhe $G$, Enquselassie $F$, Aseffa A. Assessment of risk factors for development of active pulmonary tuberculosis in northern part of ethiopia: a matched case control study. Ethiop Med J. 2013;51(4):227-37.

42. Whitehead SJ, Ali S. Health outcomes in economic evaluation: the QALY and utilities. Br Med Bull. 2010;96(1):5-21. https://doi.org/10.1093/bmb/ Idq033.

43. Land for Healing: Developing a First Nations Land- based Service Delivery Model, ( ) Thunderbird Partnership Foundation, 22361 Austin Line, Bothwell, Ontario, 2018. https://thunderbirdpf.org/wp-content/uploads/2018/07/ Thunderbirdpf-LandforHealing-Document-SQ.pdf.

44. Indigenous Services Canada: Feature stories. ISC and Nunavut government partner to fund mobile addiction treatment program. Government of Canada; 2019. https://www.sac-isc.gc.ca/eng/1548425217756/154 8425244542.

45. PRA Inc. Information Info Strategy. Health Canada Evaluation of the Canada Prenatal Nutrition Program (CPNP). Health Canada. 2004. http://publications. gc.ca/collections/collection_2016/sc-hc/H14-163-2004-eng.pdf.

46. Niqinik Nuatisivik Nunavut Food Bank. Inuit Tapiriit Kanatami: Nuluaq Mapping Project. 2018. https://www.itk.ca/nuluaq-mapping-project/ initiative/niqinik-nuatsivik-nunavut-food-bank/.

47. The Canada Prenatal Nutrition Program: A Decade of Promoting the Health of Mothers, Babies and Communities. Public Health Agency of Canada, Division of Childhood and ADolescene, Centre for Health Promotion. 2007. http://publications. gc.ca/collections/collection_2012/aspc-phac/HP10-11-2007-eng.pdf.

48. Department of Economic Development and Transportation. 2015-16 Annual Report: Country Food Distribution Program. Government of Nunavut. 2017. https://www.gov.nu.ca/sites/default/files/edt-2017-cfdp-ar_eng.pdf.

49. Department of Economic Development and Transportation. 2018-2019 Programs and Funding. Government of Nunavut. 2019. https://gov.nu.ca/ sites/default/files/program_overview_pamphlet_eng_0.pdf.

50. Riva M, Fletcher C, Dufresne P, Perreault K, Muckle G, Potvin L, Bailie RS. Relocating to a new or pre-existing social housing unit: significant health improvements for Inuit adults in Nunavik and Nunavut. Can J Public Health. 2020;111(1):21-30. https://ink.springer.com/content/pdf/10.17269/s41997-01900249-6.pdf.

51. Levy DT, Hyland A, Higbee C, Remer L, Compton C. The role of public policies in reducing smoking prevalence in California: results from the California tobacco policy simulation model. Health Pol. 2007;82(2):167-85. https://www.ncbi.nlm.nih.gov/pmc/ articles/PMC2743269/pdf/nihms25327.pdf

52. Levy D, de Almeida LM, Szklo A. The Brazil SimSmoke policy simulation model: the effect of strong tobacco control policies on smoking prevalence and smoking-attributable deaths in a middle income nation. PLoS Med. 2012;9(11):e1001336. https://www.ncbi.n/m.nih.gov/pmc/articles/PMC3491 001/pdf/pmed.1001336.pdf.

53. Thompson S, Kamal AG, Alam MA, Wiebe J. Community development to feed the family in Northern Manitoba Communities: evaluating food activities based on their food sovereignty, food security, and sustainable livelihood outcomes. Can J
Nonprofit Soc Econ Res. 2012;3(2):43-66. https:/anserj.ca/index.php/cjnser/article/ view/121/67.

54. Wright S, Nebelkopf E, King J, Maas M, Patel C, Samuel S. Holistic system of care: evidence of effectiveness. Subst Use Misuse. 2011;46(11):1420-30.

55. Marley JV, Atkinson D, Kitaura T, Nelson C, Gray D, Metcalf S, et al. The Be Our Ally Beat Smoking (BOABS) study, a randomised controlled trial of an intensive smoking cessation intervention in a remote aboriginal Australian health care setting. BMC Public health. 2014;14(1):32.

56. Levy DT, Chaloupka F, Gitchell J. The effects of tobacco control policies on smoking rates: a tobacco control scorecard. J Public Health Manag Pract. 2004; 10(4):338-53.

57. Bougie E, Kohen D. Smoking prevalence among Inuit in Canada. Health Reports. 2017; Statistics Canada Catalogue no. 82-003-X. https://www150. statcan.gc.ca/n1/en/pub/82-003-x/2017002/article/14773-eng.pdf?st=DYMe5 rG5.

58. Statistics Canada. Table 13-10-0539-01 Frequency of drinking in the past 12 months, by age group and sex, household population aged 12 and over who are current drinkers, territories. https://doi.org/10.25318/1310053901eng.

59. Ledrou I, Gervais J. Food Insecurity. Health Reports. 2005;16(3):47-51. Statistics Canada, Catalogue no. 82-003. https://www150.statcan.gc.ca/n1/ en/pub/82-003-x/2004003/article/7841-eng.pdf?st=vFM7l8SL.

60. Egeland GM. IPY Inuit Health Survey speaks to need to address inadequate housing, food insecurity and nutrition transition. International J Circumpolar Health. 2011;70(5):444-6. https://www.tandfonline.com/doi/pdf/10.3402/ijch. v70i5.17854? needAccess=true.

61. Tarasuk V, Mitchell A, Dachner N. Household Food Insecurity in Canada, 2014. Toronto. Research to identify policy options to reduce food insecurity (PROOF). 2016.

62. Aboriginal Peoples in Canada in 2006: Inuit, Métis and First Nations, 2006 Census. Aboriginal Peoples, 2006 Census, Census year 2006. Statistics Canada Catalogue no. 97-558-XIE. https://www12.statcan.gc.ca/censusrecensement/2006/as-sa/97-558/pdf/97-558-XIE2006001.pdf.

63. Census in Brief: The housing conditions of Aboriginal people in Canada Census of Population, 2016. Statistics Canada Catalogue no. 98-200X2016021. https://www12.statcan.gc.ca/census-recensement/2016/as-sa/98-2 00-x/2016021/98-200-x2016021-eng.pdf.

64. Bank of Canada. Inflation calculator, Bank of Canada. The Consumer Price Index, Statistics Canada. 2018. http://www.bankofcanada.ca/rates/related/ inflation-calculator/.

65. King BA, Pechacek TF, Mariolis P. Best practices for comprehensive tobacco control programs, 2014. 2014. https://www.cdc.gov/tobacco/ stateandcommunity/best_practices/pdfs/2014/comprehensive.pdf.

66. Service des relations avec la clientèle. List of Medications. RAMQ, editor. Quebec: Bibliothèque et Archives nationales du Québec, 2017; 2017. p. 642 http://www.ramq.gouv.qc.ca/en/citizens/prescription-drug-insurance/Pages/ prescription-drugs-covered.aspx.

67. Inuit Tapiriit Kanatami. Inuit Nunangat Housing Strategy. Government of Canada. 2019; ISBN: 978-1-989179-25-3. https://www.itk.ca/wp-content/ uploads/2019/04/2019-Inuit-Nunangat-Housing-Strategy-English.pdf.

68. Nunavut Housing Corporation. Nunavut Housing Corporation Annual Report 2016-17. Legislative Assembly of Nunavut. 2017;372-4(3). https:/assembly.nu.ca/ sites/default/files/TD-372-4(3)-EN-NHC-2016-2017-Annual-Report_0.pdf.

69. Pauktuutit Inuit Women of Canada. Facilitator's Guide, Atii! Reduce SecondHand Smoke. In: Pauktuutit Inuit Women of Canada, editor. Canada. 2012. http://pauktuutit.ca/wp-content/blogs.dir/1/assets/Pauktuutit-ATII-FGPhase2-English.pdf.

70. Prochaska JJ, Delucchi K, Hall SM. A meta-analysis of smoking cessation interventions with individuals in substance abuse treatment or recovery. J Consult Clin Psychol. 2004;72(6):1144. https:/cloudfront.escholarship.org/dist/prd/content/ qt0r8673wv/qt0r8673w.pdf?t=Inrsdv.

71. Statistics Canada. Table 13-10-0418-01 Crude birth rate, age-specific fertility rates and total fertility rate (live births). https://doi.org/10.25318/ 1310041801-eng.

72. Sugarman J, Alvarez G, Schwartzman K, Oxlade O. Sputum induction for tuberculosis diagnosis in an Arctic setting: a cost comparison. Int J Tuberc Lung Dis. 2014;18(10):1223-30.

73. Tan M, Menzies D, Schwartzman K. Tuberculosis screening of travelers to higherincidence countries: a cost-effectiveness analysis. BMC Public Health. 2008;8(1):201.

74. Ontario Ministry of Health and Long-Term Care. Schedule of Benefits, Physician Services Under the Health Insurance Act: Ministry of Health and 
Long-Term Care; 2015. http://www.health.gov.on.ca/en/pro/programs/ohip/ sob/physserv/sob_master11062015.pdf.

75. Thomson H, Thomas S, Sellstrom E, Petticrew M. The health impacts of housing improvement: a systematic review of intervention studies from 1887 to 2007. Am J Public health. 2009;99(S3):S681-92. https://ajph. aphapublications.org/doi/full/10.2105/AJPH.2008.143909.

76. Ruiz-Castell M, Muckle G, Dewailly É, Jacobson JL, Jacobson SW, Ayotte P, Riva M. Household crowding and food insecurity among Inuit families with school-aged children in the Canadian Arctic. Am J Public Health. 2015; 105(3):e122-32. https://ajph.aphapublications.org/doi/pdf/10.2105/AJPH.2 014.302290.

77. Canadian Agency for Drugs and Technologies in Health (CADTH). CADTH Methods and Guidelines: Guidelines for the Economic Evaluation of Health Technologies: Canada, 4th Edition. 2017. https://www.cadth.ca/sites/default/ files/pdf/guidelines_for_the_economic_evaluation_of_health_technologies_ canada_4th_ed.pdf.

78. Cameron D, Ubels J, Norström F. On what basis are medical costeffectiveness thresholds set? Clashing opinions and an absence of data: a systematic review. Global Health Action. 2018;11(1):1447828. https://www. ncbi.nlm.nih.gov/pmc/articles/PMC5930346/.

79. Inuit Tapiriit Kanatami. Inuit Tuberuclosis Elimination Framework. 2018. https://www.itk.ca/wp-content/uploads/2018/12/FINAL-ElectronicEN-InuitTB-Elimination-Framework.pdf.

80. Ivers RG, Castro A, Parfitt D, Bailie RS, D'Abbs PH, Richmond RL. Evaluation of a multi-component community tobacco intervention in three remote Australian Aboriginal communities. Aust New Zealand J Public Health. 2006; 30(2):132-6. https://onlinelibrary.wiley.com/doi/epdf/10.1111/j.1467-842X.2 006.tb00105.x.

81. Lichtenstein E, Glasgow RE, Lopez K, Hall R, McRae SG, Meyers GB. Promoting tobacco control policies in northwest Indian tribes. Am J Public Health. 1995;85(7):991-4. https://ajph.aphapublications.org/doi/pdf/10.2105/ A.JPH.85.7.991.

82. Mendham AE, Duffield R, Marino F, Coutts AJ. A 12-week sports-based exercise programme for inactive Indigenous Australian men improved clinical risk factors associated with type 2 diabetes mellitus. J Sci Med Sport. 2015;18(4):438-43. https://www.sciencedirect.com/science/article/abs/pii/ $S 1440244014001248$

83. Nicholson A, Borland R, Bennet P, Davey M, Sarin J, Van der Sterren A, Stevens $M$, Thomas $D$. The effect of pack warning labels on quitting and related thoughts and behaviors in a national cohort of Aboriginal and Torres Strait Islander smokers. Nicotine Tobacco Res. 2017;19(10):1163-71. https://academic.oup.com/ntr/article-abstract/19/10/1163/2871245.

84. Ong KS, Carter R, Vos T, Kelaher M, Anderson I. Cost-effectiveness of interventions to prevent cardiovascular disease in Australia's indigenous population. Heart Lung Circ. 2014;23(5):414-21. https://www.sciencedirect. com/science/article/pii/S1443950613013152.

85. Magnus A, Cobiac L, Brimblecombe J, Chatfield M, Gunther A, Ferguson M, Moodie M. The cost-effectiveness of a $20 \%$ price discount on fruit, vegetables, diet drinks and water, trialled in remote Australia to improve Indigenous health. PloS one. 2018;13(9):e0204005. https://journals.plos.org/ plosone/article?id=10.1371/journal.pone.0204005.

86. Reilly R, Evans K, Gomersall J, Gorham G, Peters MD, Warren S, O'Shea R, Cass A, Brown A. Effectiveness, cost effectiveness, acceptability and implementation barriers/enablers of chronic kidney disease management programs for Indigenous people in Australia, New Zealand and Canada: a systematic review of mixed evidence. BMC health services research. 2016; 16(1):119. https://link.springer.com/article/10.1186/s12913-016-1363-0.

87. Angus C, Thomas C, Anderson P, Meier PS, Brennan A. Estimating the costeffectiveness of brief interventions for heavy drinking in primary health care across Europe. Eur J Public Health. 2017;27(2):345-51. https://academic.oup. com/eurpub/article/27/2/345/2622407?login=true.

88. Solberg LI, Maciosek MV, Edwards NM, Khanchandani HS, Goodman MJ. Repeated tobacco-use screening and intervention in clinical practice: health impact and cost effectiveness. Am J Prev Med. 2006;31(1):62-71. https:// www.sciencedirect.com/science/article/pii/S0749379706001255.

89. Lönnroth K, Glaziou P, Weil D, Floyd K, Uplekar M, Raviglione M. Beyond UHC: monitoring health and social protection coverage in the context of tuberculosis care and prevention. PLoS Med. 2014;11(9):e1001693. https:// journals.plos.org/plosmedicine/article?id=10.1371/journal.pmed.1001693.
90. Lönnroth K, Jaramillo E, Williams BG, Dye C, Raviglione M. Drivers of tuberculosis epidemics: The role of risk factors and social determinants. Soc Sci Med. 2009;68(12):2240-6. https://doi.org/10.1016/j.socscimed.2009.03.041.

91. Lönnroth K, Castro KG, Chakaya JM, Chauhan LS, Floyd K, Glaziou P, et al. Tuberculosis control and elimination 2010-50: cure, care and social development. Lancet. 2010;375(9728):1814-29. https://doi.org/10.1016/ S0140-6736(10)60483-7.

92. Rasanathan K, Sivasankara Kurup A, Jaramillo E, Lönnroth K. The social determinants of health: key to global tuberculosis control. Int Union Against Tuberc Lung Dis. 2011 June;15(2):S30-6. https://doi.org/10.5588/ijtld.10.0691.

93. Hargreaves JR, Boccia D, Evans CA, Adato M, Petticrew M, Porter JDH. The social determinants of tuberculosis: from evidence to action. Am J Public Health. 2011;101(4):654-62. https:/doi.org/10.2105/AJPH.2010.199505.

94. Tester FJ, Kulchyski P. Taamarniit (Mistakes): Inuit relocations in the Eastern Arctic 1939-63. Vancouver: UBC Press; 1994. Print.

95. Patterson M, Finn S, Barker K. Addressing tuberculosis among Inuit in Canada. Can Commun Dis Rep. 2018;44(3/4):82-5. https://doi.org/10.14745/ ccdr.v44i34a02.

\section{Publisher's Note}

Springer Nature remains neutral with regard to jurisdictional claims in published maps and institutional affiliations.
Ready to submit your research? Choose BMC and benefit from:

- fast, convenient online submission

- thorough peer review by experienced researchers in your field

- rapid publication on acceptance

- support for research data, including large and complex data types

- gold Open Access which fosters wider collaboration and increased citations

- maximum visibility for your research: over $100 \mathrm{M}$ website views per year

At BMC, research is always in progress.

Learn more biomedcentral.com/submissions 